\title{
The importance of prostaglandin synthesis for the initiation of blastocyst implantation in the hamster
}

\author{
C. A. Evans and T. G. Kennedy \\ Departments of Physiology and Obstetrics \& Gynaecology, University of Western Ontario, \\ London, Ontario, Canada N6A 5 A5
}

\begin{abstract}
Summary. In hamsters, localized areas of increased uptake of Evans Blue dye, representing the first uterine sign of blastocyst implantation, had an increased concentration of PGE and their appearance on Day 4 was prevented by treatment with indomethacin, an inhibitor of $\mathrm{PG}$ synthesis. Indomethacin treatment did not terminate pregnancy: the proportion of animals pregnant on Days 5, 7,10 and 16 was not affected, although fetal mortality was slightly greater in these animals. Indomethacin treatment caused a decrease in the weights of Evans Blue sites on Day 5 and implantation swellings on Day 10 , and the duration of gestation was slightly increased, indicating that implantation had been delayed. This delay did not result from changes of circulating progesterone levels or uterine blood supply. The PG synthesis inhibitors, indomethacin and meclofenamic acid reduced uterine PG concentrations and prevented the appearance of Evans Blue sites in ovariectomized pregnant hamsters treated with progesterone. It is suggested that PGs may be mediators in the uterine Evans Blue response which precedes implantation in the hamster.
\end{abstract}

\section{Introduction}

The earliest known step in the series of interactions between the ovum and the endometrium which leads to implantation is increased vascular permeability in uterine areas surrounding the blastocysts. This increase leads to an accelerated passage of plasma proteins into the extravascular tissues, and has been conşidered essential for decidual cell formation (Psychoyos, 1973). In the hamster, increased vascular permeability, as determined by the localized accumulation of a macromolecular dye from the circulation, occurs on the evening of Day 4 of pregnancy (Orsini, 1963), 15-20 h before morphological signs of trophoblastic invasion.

The nature and origin of the signal(s) which initiate implantation and decidual cell formation are uncertain. Histamine has been proposed as a mediator (Shelesnyak, 1954), but its role still remains controversial (Humphrey \& Martin, 1968; Psychoyos, 1973). More recently, it was suggested that oestrogen of blastocyst origin may be involved (Dickmann, Dey \& Sen Gupta, 1976), but there is no conclusive evidence for mouse blastocyst steroidogenesis (Sherman \& Atienza, 1977). Prostaglandins have been proposed as mediators of the uterine vascular response during the initiation of implantation in rats (Kennedy, 1977). Indomethacin, an inhibitor of prostaglandin synthesis (Flower, 1974), delays the appearance of this vascular response (Kennedy, 1977) and inhibits decidualization (Sananes, Baulieu \& LeGoascogne, 1976; Tobert, 1976) in rats. Prostaglandin levels were elevated in uterine areas of increased permeability (Kennedy, 1977), and, when instilled in the uterine lumen of prepubertaf rats treated with progesterone, prostaglandin (PG) F-2 $\alpha$ induced a decidual response (Sananes et al., 1976). Prostaglandins have also been proposed as mediators of increased vascular permeability occurring during the inflammatory response (Crunkhorn \& Willis, 1971; Williams \& Morley, 1973). The present investigation tested the hypothesis that increases in endometrial vascular permeability preceding ovum implantation in the hamster are mediated by prostaglandins. 


\section{Materials and Methods}

\section{Animals and treatments}

Mature female golden hamsters (120-130 g) were obtained from Lakeview Hamster Colony Farms, Newfield, New Jersey, U.S.A., and housed under temperature- and light-controlled conditions (lights on from $05: 00$ to 19:00 h), with free access to food and water. Hamsters were acclimatized for at least 8 days before being placed with males of proven fertility. Vaginal smears were examined each morning and only females with spermatozoa in the post-oestrous discharge (designated Day 1 of pregnancy) were used in the experiments.

Indomethacin and meclofenamic acid, inhibitors of PG synthesis (Flower, 1974; Ferreira, Flower, Moncada \& Vane, 1975), were administered subcutaneously at 05:00, 10:00 and 15:00 h on Day 4 in $0.2 \mathrm{ml}$ sesame oil in the amounts indicated in the 'Results'; control animals received an equal volume of oil.

The effects of these inhibitors were also examined in some hamsters which were bilaterally ovariectomized under ether anaesthesia on Day 3 of pregnancy. Uterine responsiveness to ovum implantation was maintained in these animals by giving $4 \mathrm{mg}$ progesterone subcutaneously on Days 3 and 4 of pregnancy (Harper, Dowd \& Elliott, 1969).

\section{Endometrial vascular permeability}

Hamsters were anaesthetized with ether and, 30 min before autopsy, were given $0.25 \mathrm{ml} 1 \%$ Evans Blue in $0.9 \%(\mathrm{w} / \mathrm{v}) \mathrm{NaCl} / 100 \mathrm{~g}$ body weight via the femoral vein. After decapitation the uteri were examined for areas stained with Evans Blue (Evans Blue sites).

To measure the intensity of the response, the Evans Blue sites and non-blue areas of the uterus were dissected and weighed to the nearest $0.1 \mathrm{mg}$. Transition zones between such areas were discarded. Concentrations of Evans Blue were determined spectrophotometrically, in the uterus by the method of Udaka, Takeuchi \& Movat (1970) and in plasma by that described by Allen, Ochoa, Roth \& Gregersen (1953).

\section{Weight of implantation swellings and fetal development}

The uteri were removed and cleaned of extraneous tissue. Implantation swellings were counted, dissected by cutting the uterine horns tangential to the swellings, and weighed to the nearest $1 \mathrm{mg}$. Fetuses in implantation swellings on Day 10 of pregnancy were removed and examined under a dissecting microscope: a fetus with a beating heart was considered viable.

Hamsters were observed at 15-min intervals on Day 16 of pregnancy and the time of parturition was recorded at the time when the first young was observed. When parturition was complete, litter size was recorded for each animal. Animals not giving birth by Day 17 were killed and examined for uterine swellings or resorption sites.

\section{Radioimmunoassays}

Plasma progesterone. Blood was collected in heparinized culture tubes. Plasma was separated by centrifugation and stored at $-20^{\circ} \mathrm{C}$ until a petroleum ether extract was assayed by the method of Abraham, Swerdloff, Tulchinsky \& Odell (1971). An antiserum to progesterone-11 $\alpha$-bovine serum albumin with a cross-reactivity of $9 \cdot 2 \%$ for $5 \beta$-pregnane-3,20-dione, $8 \cdot 6 \%$ for $5 \alpha$-pregnane-3,20-dione,

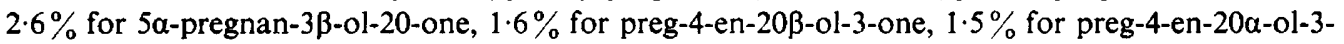
one and $1.0 \%$ for $5 \alpha$-pregnan-3 $\alpha$-ol-20-one was used for the assay. Cross-reactivity for an additional 20 steroids was less than $1 \%$. All samples were assayed at the same time with an intra-assay coefficient of variation of $4 \%(n=25)$, and a sensitivity of $25 \mathrm{pg}$.

Uterine prostaglandins. At autopsy the uteri were removed and placed for at least $2 \mathrm{~min}$ in an icecold bath of $0.9 \% \mathrm{NaCl}$ containing $20 \mu \mathrm{g}$ indomethacin $/ \mathrm{ml}$. They were then cleaned of extraneous tissue and Evans Blue sites were separated from non-blue areas with a scalpel blade. All tissue was cut to about equal lengths so that trauma was approximately equal for the two groups of pooled tissues. Each pool was weighed to the nearest $0.1 \mathrm{mg}$, placed in $1 \mathrm{ml}$ ice-cold ethanol and stored at $-20^{\circ} \mathrm{C}$ until 
all samples were collected. The samples were homogenized in ice-cold ethanol and assayed for PGE and PGF as described by Behrman (1971), using PGE-2 and PGF-2 $\alpha$, respectively, as standards. The antiserum used for the PGE assay did not differentiate between the different $E$ prostaglandins and also cross-reacted with PGA and PGB; the antiserum used for the PGF assay did not differentiate between the different $F$ prostaglandins. The sensitivity of both assays was approximately $5 \mathrm{pg}$ and the intra-assay coefficient of variation was $4 \%(n=15)$ for PGE and $5 \%(n=15)$ for PGF. All samples were assayed at the same time for each experiment.

\section{Statistical analysis}

The data are presented as proportions or as means \pm s.e.m., the latter being based on betweenanimal variation in all cases. The significance of treatment effects was determined by $\chi^{2}$ analysis, by paired and unpaired $t$ tests and by Duncan's New Multiple Range Test, as indicated in the 'Results'.

\section{Results}

Effect of indomethacin on the uterine Evans Blue response and plasma progesterone concentrations

The implantation sites in intact control animals contained more Evans Blue than did the rest of the uterus (Table 1). Although none of the uteri in the indomethacin-treated animals showed specific Evans Blue sites, the concentration of Evans Blue in the uteri was similar to that of the non-blue areas in control hamsters.

Table 1. The effects of indomethacin ( $\mathrm{Img} / \mathrm{l} 00 \mathrm{~g}$ body wt in oil at $05: 00,10: 00$ and $15: 00 \mathrm{~h}$ on Day 4 ) on the uterine Evans Blue response and Evans Blue concentrations in intact hamsters killed at about $21: 00 \mathrm{~h}$ on Day 4 of pregnancy

\begin{tabular}{lcc}
\hline & Sesame oil (control) & Indomethacin \\
\hline Proportion with Evans Blue sites & $9 / 9 \dagger$ & $0 / 8 \dagger$ \\
Evans Blue concentrations (mean \pm s.e.m.) & $436 \cdot 9 \pm 42 \cdot 7$ & $368 \cdot 6 \pm 24 \cdot 5$ \\
Plasma $(\mu \mathrm{g} / \mathrm{ml})$ & $28 \cdot 8 \pm 3 \cdot 0^{*}$ & - \\
Evans Blue sites $(\mathrm{ng} / \mathrm{mg})$ & $20 \cdot 8 \pm 2 \cdot 2^{*}$ & $18 \cdot 7 \pm 1 \cdot 1$ \\
Non-blue areas $(\mathrm{ng} / \mathrm{mg})$ & \\
\hline
\end{tabular}

$$
\begin{aligned}
& * P<0.01 \text { (paired } t \text { test). } \\
& \dagger P<0.001 \text { ( } \chi^{2} \text { test). }
\end{aligned}
$$

The uterine Evans Blue response and plasma progesterone concentrations were examined in hamsters receiving oil or $0 \cdot 2,0 \cdot 4,0 \cdot 6$, or $0 \cdot 8 \mathrm{mg}$ indomethacin $/ 100 \mathrm{~g}$ body weight at $05: 00,10: 00$ and 15:00 h on Day 4, and killed at $21: 00 \mathrm{~h}$ that day, $30 \mathrm{~min}$ after injection of Evans Blue. There was a significant decrease $\left(P<0.05, \chi^{2}\right.$ test $)$ in the proportion of uteri with Evans Blue sites following treatment with the $0.8 \mathrm{mg}$ dose (3/9) than in those of control hamsters $(6 / 6)$, but the plasma progesterone concentration did not change $(22.9 \pm 4.6 \mathrm{ng} / \mathrm{ml}$ and $19.6 \pm 1 \cdot 8 \mathrm{ng} / \mathrm{ml}$, respectively). Progesterone concentrations and the proportions of uteri with Evans Blue sites in animals treated with lower doses of indomethacin did not differ significantly from controls.

\section{Uterine Evans Blue response in ovariectomized hamsters}

As shown in Table 2, meclofenamic acid and indomethacin significantly decreased the proportion of ovariectomized, progesterone-treated hamsters with Evans Blue sites and in non-blue uterine areas of these hamsters there was a significant decrease in the concentrations of both PGs.

\section{Prostaglandin concentrations in Evans Blue sites}

Uterine PG concentrations were measured at $21: 00 \mathrm{~h}$ on Day 4 in 7 intact, untreated hamsters which had 10.6 \pm 0.5 Evans Blue sites/uterus. The concentration of PGE was significantly higher $(P<0.01$, paired $t$ test $)$ in Evans Blue sites $(8.4 \pm 0.8 \mathrm{pg} / \mathrm{mg})$ than in non-blue areas $(4.8 \pm 0.4 \mathrm{pg} / \mathrm{mg})$, while the concentration of PGF did not differ $\left(4 \cdot 6 \pm 0.4\right.$ and $3.9 \pm 0.5 \mathrm{pg} / \mathrm{mg}_{\mathrm{t}}$ respectively). 
Table 2. The effects of indomethacin ( $1 \mathrm{mg} / 100 \mathrm{~g}$ body $w \mathrm{t}$ ) and meclofenamic acid $(1.5 \mathrm{mg} / 100 \mathrm{~g}$ body $\mathrm{wt})$ on the uterine Evans Blue response and prostaglandin (PG) concentrations (mean \pm s.e.m.) in non-blue uterine tissue in ovariectomized, progesterone-treated hamsters killed about 22:00 h on Day 4 of pregnancy

\begin{tabular}{|c|c|c|c|}
\hline \multirow[b]{2}{*}{ Treatment } & \multirow{2}{*}{$\begin{array}{l}\text { Proportion with } \\
\text { Evans Blue sites }\end{array}$} & \multicolumn{2}{|c|}{ PG conc. (pg/mg wet wt) } \\
\hline & & PGE & PGF \\
\hline Sesame oil & $8 / 8$ & $1 \cdot 50 \pm 0.20$ & $1 \cdot 70 \pm 0 \cdot 30$ \\
\hline Indomethacin & $1 / 9 * *$ & $0.14 \pm 0.02 \dagger$ & $0.20 \pm 0.03 \dagger$ \\
\hline Meclofenamic acid & $4 / 9^{*}$ & $0.11 \pm 0.01 \dagger$ & $0.40 \pm 0.10 \dagger$ \\
\hline
\end{tabular}

Values significantly different compared with control value: ${ }^{*} P<0.01$, ** $P<0.001$ ( $\chi^{2}$ test) $\dagger P<0.001$ (Duncan's New Multiple Range test).

\section{Effect of indomethacin treatment on Day 4 on blastocyst implantation and survival}

To determine if implantation was initiated at a later time in indomethacin-treated hamsters. animals were treated with oil or $1 \mathrm{mg}$ indomethacin/100 $\mathrm{g}$ body wt at 05:00, 10:00 and 15:00 h on Day 4 and killed at $08: 00 \mathrm{~h}$ on Day 5, $30 \mathrm{~min}$ after the injection of Evans Blue. Indomethacin treatment had no significant effect on the proportion of uteri with Evans Blue sites $(7 / 10$, compared with $6 / 10$ for the controls), or on the number of sites per uterus (11.4 \pm 1.0 and $12.0 \pm 0.5$, respectively). However, the treatment was associated with a significant decrease $(P<0.05, t$ test $)$ in the mean weight of these areas $(12.0 \pm 0.7 \mathrm{mg}$ versus $14.2 \pm 0.4 \mathrm{mg}$ for controls).

Longer-term effects were examined in hamsters treated with oil or indomethacin on Day 4, as before, and killed at 13:00 h on Day 7 or Day 10 of pregnancy. Although the proportions of hamsters with implantation swellings were not affected, the numbers and weights of implantation swellings were significantly decreased in the indomethacin-treated animals (Table 3). Fetuses taken from indomethacin-treated animals on Day 10 appeared smaller and less developed, as determined by limb differentiation and the appearance of eyes, than fetuses taken from controls. Indomethacin treatment on Day 4 had no effect on the proportion of hamsters giving birth on Day 16 (6/8 compared to 7/8 in controls), but significantly decreased $(P<0.001, t$ test $)$ the number of young born $(5 \cdot 3 \pm 0.3$ compared with 13.7 \pm 0.4 in controls), and delayed $(P<0.001, t$ test $)$ the time of parturition on Day 16 (16:15 \pm $00: 54 \mathrm{~h}$ compared with $07: 54 \pm 00: 45 \mathrm{~h}$ in controls). There were no signs of resorption in the animals that did not give birth.

Table 3. The effects of indomethacin $(1 \mathrm{mg} / 100 \mathrm{~g}$ body wt in oil at 05:00, 10:00 and 15:00 $\mathrm{h}$ on Day 4) on implantation in hamsters killed about $33: 00 \mathrm{~h}$ on Days 7 or 10 of pregnancy

\begin{tabular}{|c|c|c|c|c|}
\hline & \multicolumn{2}{|c|}{ Killed on Day 7} & \multicolumn{2}{|c|}{ Killed on Day 10} \\
\hline & Sesame oil & Indomethacin & Sesame oil & Indomethacin \\
\hline Proportion pregnant & $6 / 9$ & $7 / 9$ & $8 / 9$ & $7 / 9$ \\
\hline Total no. of swellings/hamster & $14 \cdot 7 \pm 0 \cdot 6$ & $8.9 \pm 1 \cdot 3^{* *}$ & $14.9 \pm 0.6$ & $11 \cdot 0 \pm 1.4^{*}$ \\
\hline Wt of swelling/hamster & $94 \cdot 8 \pm 2 \cdot 7$ & $67 \cdot 7 \pm 5 \cdot 0^{* *}$ & $434.4 \pm 19 \cdot 3$ & $232 \cdot 3 \pm 19 \cdot 3 * *$ \\
\hline Viable swellings & & & & \\
\hline Number & & & $14 \cdot 1 \pm 0.6$ & $5 \cdot 1 \pm 0 \cdot 8^{* * *}$ \\
\hline Weight (mg) & & & $450.6 \pm 16.6$ & $367 \cdot 8 \pm 22 \cdot 4^{* *}$ \\
\hline Non-viable swellings & & & & \\
\hline Number & & & $0.7 \pm 0.2$ & $5 \cdot 9 \pm 1 \cdot 1 * * *$ \\
\hline Weight (mg) & & & $128 \cdot 7 \pm 19 \cdot 1$ & $102.7 \pm 7.9$ \\
\hline
\end{tabular}

Values are mean \pm s.e.m. for those animals pregnant.

Values significantly different compared with respective control: $\boldsymbol{P}_{\mathrm{B}}<\mathbf{0 . 0 2},{ }^{* \boldsymbol{*}} \boldsymbol{P}<\mathbf{0 . 0 1}, \boldsymbol{*} \boldsymbol{*} \boldsymbol{*} \boldsymbol{P}<\mathbf{0 . 0 0 1}$, 


\section{Discussion}

The present results support the hypothesis that PGs are mediators of the increased endometrial vascular permeability which precedes blastocyst implantation. Similar results have been reported for the rat (Kennedy, 1977). Inhibition of PG synthesis may have prevented the uterine Evans Blue response on Day 4 by a direct action on endometrial vascular permeability. An indirect action via the uterine blood supply seems unlikely because there were no measurable changes in basal concentrations of Evans Blue in the uteri of indomethacin-treated animals. However, indomethacin may have acted by preventing a local, PG-mediated, blastocyst-induced vasodilatation which may be essential for changes in vascular permeability. Williams \& Peck (1977) report that indomethacin inhibits the increased vascular permeability which occurs during the inflammatory response in rabbit skin by preventing vasodilatation.

The weights of Evans Blue sites on Day 5 and of implantation swellings on Days 7 and 10 were lower in treated animals. This may result from a delay of implantation or a decreased rate of decidual cell formation. Castracane, Saksena \& Shaikh (1974) reported that indomethacin inhibits the decidual cell reaction in pseudopregnant rats but this action may have been secondary to inhibition of endometrial vascular permeability. Indomethacin treatment delays implantation in the rat (Kennedy, 1977) and the results of the present experiments showing the delayed onset of the uterine Evans Blue response, the decreased size of implantation swellings, the smaller and less developed Day-10 fetuses, and the prolonged gestation period all suggest that indomethacin treatment delays implantation in the hamster. However, indomethacin also reduced litter size, and although a decrease in total fetal mass increases the gestation period in mice (McLaren, 1967), the delays in parturition and in the uterine Evans Blue response are of the same order, so it seems likely that decreased litter size contributed little to the prolonged gestation period.

The possibility that indomethacin was toxic to Day-4 hamster blastocysts cannot be ruled out, although indomethacin treatment does not influence viability in rabbits (Hoffman, 1977) or in rats (Kennedy, 1977). The reduction in litter size and number of implantation swellings in hamsters may result rather from a poor embryonic capacity to endure a delay in implantation. Weitlauf (1971) suggested that the inability of hamster embryos to reduce their metabolism, unlike mouse embryos, following ovariectomy, may explain why hamster embryos rapidly degenerate while mouse embryos remain viable for prolonged periods. In the present experiments, embryos in indomethacin-treated animals were older at the time implantation was initiated, and some embryos may exhaust their nutritive supply before implantation is complete.

Since progesterone is essential for implantation in the hamster (Prasad, Orsini \& Meyer, 1960), the effect of indomethacin on the uterine Evans Blue response may have resulted from some modification of ovarian steroidogenesis. However, indomethacin did not reduce plasma progesterone levels in intact hamsters, and both indomethacin and meclofenamic acid, chemically dissimilar inhibitors of PG synthesis, inhibited the Evans Blue response in ovariectomized animals treated with progesterone. Moreover, this was associated with a reduction in the uterine concentrations of PGE and PGF, supporting the assumption that these drugs are inhibiting PG synthesis. These findings agree with those of Kennedy (1977) for rats.

As in the rat (Kennedy, 1977) the concentration of PGs of the E series was elevated in Evans Blue sites in the hamster uterus. However, it is difficult to determine whether this elevation is a cause or a consequence of increased endometrial vascular permeability. Prostaglandins other than PGE may mediate the Evans Blue response because indomethacin inhibits the synthesis of all PGs and PGG-2, an intermediate in PGE and PGI-2 synthesis, has been proposed as the prime factor which increases vascular permeability in acute inflammation, PGE being responsible only for the accompanying vasodilatation (Kuehl et al., 1977). The principal metabolite of PGI-2, 6-keto-PGF-1 $\alpha$, is synthesized in 10-20 times greater amounts than PGE by homogenates of pseudopregnant rat uteri (Fenwick, Jones, Naylor, Poyser \& Wilson, 1977). Therefore, PGI-2 may be the principal mediator of the uterine Evans Blue response, although at present its effects on vascular permeability are unknown.

The source and site(s) of action of the PGs involved in the Evans Blue response are unknown. Prostaglandin synthesis may occur in the endometrium, and/or in the blastocyst. Tissue insult is $\mathbf{a}_{\odot 9}: 09: 04 \mathrm{AM}$ 
potent stimulus for PG synthesis (Piper \& Vane, 1971); blastocyst attachment or the uterine distension which follows the intraluminal instillation of deciduogenic substances may provide sufficient insult to act as stimuli for synthesis. Rabbit blastocysts contain PGE and PGF (Dickmann \& Spilman, 1975) and PGs might therefore diffuse from the blastocyst to increase vascular permeability, or play a role in blastocyst steroidogenesis as proposed by Dickmann et al. (1976). Finally, blastocyst oestrogen production may initiate implantation by promoting the local uterine synthesis of PGs because oestrogen is known to stimulate uterine PGF production (Saksena \& Harper, 1972).

The indomethacin and the antisera used for the prostaglandin and progesterone radioimmunoassays were a generous gift from Dr H. R. Behrman, Department of Obstetrics and Gynecology, Yale School of Medicine, New Haven, Connecticut; Dr J. E. Pike, The Upjohn Company, Kalamazoo, Michigan, provided the prostaglandins and Dr T. J. Petrick, Parke, Davis \& Company, Ann Arbor, Michigan, the meclofenamic acid. This work was supported by the Medical Research Council of Canada and the World Health Organization. T.G.K. is a Scholar of the Medical Research Council of Canada.

\section{References}

Abraham, G.E., Swerdloff, R., Tulchinsky, D. \& ODELL, W.D. (1971) Radioimmunoassay of plasma progesterone. J. clin. Endocr. Metab. 32, 619-624.

Allen, T.H., OchoA, M., JR., Roth, R.F. \& GregerSeN, M.I. (1953) Spectral absorption of T-1824 in plasma of various species and recovery of the dye by extraction. Am. J. Physiol. 175, 243-246.

BeHRMAN, H.R. (1971) Radioimmunoassay of prostaglandins. The Physiologist 14, 110.

Castracane, V.D., Saksena, S.K. \& Shaikh, A.A. (1974) Effect of IUD's, prostaglandins and indomethacin on the decidual cell reaction in the rat. Prostaglandins 6, 397-414.

Crunkhorn, P. \& Willis, W.L. (1971) Cutaneous reactions to intradermal prostaglandins. Br.J. Pharmacol. 41, 49-56.

Dickmann, Z. \& Spilman, C.H. (1975) Prostaglandins in rabbit blastocysts. Science, N.Y. 190, 997-998.

DickmanN, Z., Dey, S.K. \& Sen Gupta, J. (1976) A new concept: control of early pregnancy by steroid hormones originating in the preimplantation embryo. Vitams Horm. 34, 215-242.

Fenwick, L., Jones, R.L., NAylor, B., Poyser, N.L. \& WILSON, N.H. (1977) Production of prostaglandins by the pseudopregnant rat uterus in vitro, and the effect of tamoxifen with the identification of 6-keto-prostaglandin $\mathrm{F}_{1 \alpha}$ as a major product. Br.J. Pharmacol. 59, 191-199.

Ferreira, S.H., Flower, R., Moncada, S. \& Vane, J.R. (1975) Inhibition of prostaglandin biosynthesis as mechanism of action of non-steroid anti-infiammatory drugs. In Inflammation and Anti-Inflammatory Therapy, pp. 133-149. Eds G. Katonu \& J. Blengio. Spectrum Publication, Inc., Toronto.

FLowER, R.J. (1974) Drugs which inhibit prostaglandin biosynthesis. Pharmacol. Rev. 26, 33-67.

HARPER, M., Dowd, D. \& Ellot, A. (1969) Implantation and embryonic development in the ovariectomized hamster. Biol. Reprod. 1, 253-257.

Hoffman, L.H. (1977) Effect of indomethacin on blastocyst development and implantation in the rabbit. Anat. Rec. 187, 606, Abstr.
Humphrey, K.W. \& Martin, L. (1968) Attempted induction of deciduomata in mice with mast-cell, capillary permeability and tissue inflammatory factors. $J$. Endocr. 42, 129-141.

KENNEDY, T.G. (1977) Evidence for a role for prostaglandins in the initiation of blastocyst implantation in the rat. Biol. Reprod. 16, 286-291.

Kuehl, F.A., JR., Humes, J.L, EgaN, R.W., Ham, E.A., BeVeridge, G.C. \& VAN ARMan, C.G. (1977) Role of prostaglandin endoperoxide $P G G_{2}$ in inflammatory processes. Nature, Lond. 265, 170-173.

MCLAREN, A. (1967) Effect of foetal mass on gestation period in mice. $J$. Reprod. Fert. 13, 349-351.

OrCzyK, G.P., Hichens, M., Arth, G. \& Behrman, H.R. (1974) Progesterone. In Methods of Hormone Radioimmunoassay, pp. 347-358. Eds B. M. Jaffe \& H. R. Behrman. Academic Press, New York.

OrsinI, M.W. (1963) Morphological evidence on the intrauterine career or the ovum. In Delayed Implantation, pp. 155-166. Ed. A. C. Enders. University of Chicago Press.

Piper, P. \& VANE, J. (1971) The release of prostaglandins from the lung and other tissues. Ann. N.Y. Acad. Sci. 180, 363-385.

Prasad, M.R.N., Orsini, M.W. \& Meyer, R.K. (1960) Nidation in progesterone-treated, estrogen deficient hamsters Mesocricetus auratus (Waterhouse). Proc. Soc. exp. Biol. Med. 104, 48-51.

Psychoyos, A. (1973) Endocrine control of egg implantation. In Handbook of Physiology, Section 7, Volume II, part, 2 pp. 187-215. Eds R. O. Greep, E. G. Astwood \& S. R. Geiger. American Physiological Society, Washington, D.C.

Saksena, S.K. \& HARPER, M.J.K. (1972) Levels of F prostaglandin (PGF) in uterine tissue during the estrous cycle of hamster: effects of estradiol and progesterone. Prostaglandins 2, 405-411.

Sananes, N., Baulieu, E.E. \& LeGoascogne, C. (1976) Prostaglandin(s) as inductive factor of decidualization in the rat uterus. Mol. cell. Endocr. 6, 153-158.

ShelesNyak, M.C. (1954) The action of selected drugs on deciduoma formation. Endocrinology $55,85-89$. 
Sherman, M.I. \& Atienza, S.B. (1977) Production and metabolism of progesterone and androstenedione by cultured mouse blastocysts. Biol. Reprod. 16, 190199.

TOBERT, J.A. (1976) A stude of the possible role of prostaglandins in decidualization using a nonsurgical method for the instillation of fluids into the uterine lumen. J. Reprod. Fert. 47, 391-393.

Udaka, K., Takeuchi, Y. \& MovaT, H. (1970) Simple method for quantification of enhanced vascular permeability. Proc. Soc. exp. Biol. Med. 133, 1384-1387.
Weitlauf, H.M. (1971) Protein synthesis in vivo of preimplantation hamster embryos. Am. J. Anat. 132, 103-107.

Williams, T.J. \& Morley, J. (1973) Prostaglandins as potentiators of increased vascular permeability in inflammation. Nature, Lond. 246, 215-217.

Williams, T.J. \& Peck, M.J. (1977) Role of prostaglandin-mediated vasodilation in inflammation. Nature, Lond. 270, 530-532.

Received 6 January 1978 